1 Clarke BF, Campbell IW. Long-term comparative trial of glibenclamide and chlorpropamide in diet-failed maturity-onset diabetes. Lancet 1974; i:246-8.

2 Dahlen M, Bergman U, Idman L, Martinsson L, Karlsson G. Epidemiology of hypoglycaemia in patients on oral antidiabetic drugs in the island of Gotland, Sweden. Acta Endocrinol (suppl) 1984;263:abst 21 .

3 Potter J, Clarke P, Gale AEM, Dave SH, Tattersall RB. Insulin-induced hypoglycaemia in an accident and emergency department: the tip of an iceberg? $\mathrm{Br} \mathrm{Med} \mathcal{F}$ 1982;285:1180-2.

Barnett AH, Leslie D, Watkins PJ. Can insulin-treated diabetics be given beta-adrenergic blocking drugs? BrMed f 1980;280:976-8.

5 Muhlhauser I, Berger M, Sonnenberg G, Koch J, Jorgens V, Schernthaner G, Scholz V. Incidence and management of severe hypoglycaemia in 434 adults with insulin-dependent diabetes mellitus. Diabetes Care 1985;8:268-73.

6 Casparie AF, Elving LD. Severe hypoglycaemia in diabetic patients: frequency, causes, prevention. Diabetes Care 1985;8:141-5.

7 Tunbridge WMG. Factors contributing to deaths of diabetics under fifty years of age. Lancet 1981;ii:569-72.

8 Neil HAW, Gatling G, Mather HM, et al. The Oxford Community Diabetes Study: evidence for an increase in the prevalence of known diabetes. Diabetic Medicine 1987;4:539-43.

9 Campbell IW. Metformin and glibenclamide: comparative risks. Br Med f 1984;289:289.

10 Berger W, Caduff F, Pasquel M, Rump A. Die relative Haufigkeit der schweren SulfonylharnstoffHypoglykamie in den letzten 25 Jahren in der Schweiz. Schweiz Med Wochenschr 1986;116: $145-51$.

11 Klimt CR, Knatterud GL, Meinert CL, Prout TE. The University Group Diabetes Program: study of the effects of hypoglycemic agents on vascular complications in patients with adultonset diabetes. II. Mortality results. Diabetes 1970;19(suppl 2):747-830.

12 Fuller JH. Clinical trials in diabetes mellitus. In: Mann J, Pylorala K, Teuscher A, eds. Diabetes in epidemiological perspective, Edinburgh: Churchill Livingstone, 1983:265-85

13 UK Prospective Study of Therapies of Maturity-Onset Diabetes. I. Effect of diet, sulphonylurea insulin or biguanide therapy on fasting plasma glucose and body weight over one year. Diabetologia 1983;24:404-11.

14 Asplund K, Wiholm B-E, Lithner F. Glibenclamide-associated hypoglycaemia: a report on 57 cases. Diabetologia 1983;24:412-7.

15 Selzer HS. Drug-induced hypoglycaemia: a review based on 473 cases. Diabetes 1972;21:955-66.
16 Sonnenblick M, Shilo S. Glibenclamide induced prolonged hypoglycaemia. Age Ageing 1986;15: $185-9$.

17 Johnson SF, Schade DS, Peake GT. Chlorpropamide-induced hypoglycaemia: successful treatment with diazoxide. Am F Med 1977;63:799-804

18 Ludman P, Mason P, Joplin GS. Dangerous misuse of sulphonylureas. $\mathrm{Br}$ Med $\mathcal{F}$ 1986;293: 1287-8.

19 Ferner RE, Chaplin S. Relationship between pharmacokinetics and pharmacodynamics of oral hypoglycaemic agents. Clin Pharmokinet 1987;12:379-401.

20 Frey HMM,. Rosenlund B. Studies in patients with chlorpropamide-induced hypoglycemia. Diabetes 1970;19:930-7.

21 Rogers HJ, Spector RG, Morrison PJ, Bradbrook ID. Pharmacokinetics of intravenous glibenclamide investigated by a high performance liquid chromatographic assay. Diabetologia 1982;23:37-40

22 Matsuda A, Kuzuya T, Sugita Y, Kawashima K. Plasma levels of glibenclamide in diabetic patients during routine clinical administration determined by a specific radioimmunoassay. Horm Metab Res 1983;15:425-8.

23 Axelgaard G, Skensved H, Asfeldt VH. Hypglykaemi ved behandling med sulfonylurinstoffer. Ugeskr Laeger 1986;8:2155-8.

24 Hellman B, Sehlin J, Taljedal I-B. Glibenclamide is exceptional among hypoglycaemic agents in accumulating progressively in B-cell rich pancreatic islets. Acta Endocrinol 1984;105: 385-90.

25 Matthews EK, Shotton PA. The control of ${ }^{80} \mathrm{Rb}$ efflux from rat isolated pancreatic islets by the sulphonylureas tolbutamide and glibenclamide. Br f Pharmacol 1984;82:689-700.

26 Gale EAM. Hypoglycaemia. Clin Endocrinol Metab 1980;9:461-75.

27 Marks V, Rose FC. Hypoglycaemia. 2nd ed. Oxford: Blackwell Scientific, 1981:368.

28 Davies DM, Macintyre A, Millar EJ, Bell SM, Mehra SK. Need for glucagon in severe hypoglycaemia induced by sulphonylurea drugs. Lancet 1967; ; $363-4$

29 Pfeifer MA, Wolter CF, Samols E. Management of chlorpropamide induced hypoglycaemia with diazoxide. South Med f 1978;71:606-8.

30 Verschoor L, Uitterlinden P, Lamberts SWJ, Del Pozo E. The use of a new somatostatin analogue in the treatment of hypoglycaemia in patients with insulinoma. Clin Endocrinol 1986;25:555-60.

31 Neuvonen PJ, Karkkainen S. The effects of charcoal, sodium bicarbonate, and ammonium chloride on chlorpropamide kinetics. Clin Pharmacol Ther 1983;33:386-93.

\title{
Psychiatric illness among British Afro-Caribbeans
}

Migrants often have higher rates of mental illness than the people among whom they settle. Hence not surprisingly West Indians in Britain have an above average admission rate to psychiatric hospitals ${ }^{1-3}$ but what is unexpected is that their rate for schizophrenia should be three to five times the white rate. ${ }^{1-6}$ The explanations offered include a selective pattern of migration ${ }^{4}$; the experience of migration and "status striving in a climate of limited opportunity" ${ }^{1-8}$; a culturally determined response to adversity ${ }^{9}$; and patterns of service utilisation..$^{267}$ The question of diagnostic accuracy has also been raised ${ }^{145}$ : acute psychotic reactions, which are common as shortlived responses to stress in developing countries, may be diagnosed in Britain as schizophrenia. ${ }^{510} 11$ The misdiagnosis hypothesis may be supported by the fact that depression is less commonly diagnosed among West Indians, ${ }^{37}$ and Cochrane and Bal have recently examined the various hypotheses for the high rates of schizophrenia among British Afro-Caribbeans and emphasised misdiagnosis. ${ }^{11}$

Hospital admission figures may be misleading because patients' birthplaces are sometimes not recorded. ${ }^{12}$ Remarkably there is only one study of minor psychiatric disorder outside hospital, and it found higher rates of depression and psychosomatic illness among Afro-Caribbeans than among whites. ${ }^{13}$ It appears that depressed West Indians seldom seek psychiatric treatment, are seldom offered admission, and if they are admitted they are likely to be diagnosed as schizophrenic. Suicide among Afro-Caribbeans is less common than among whites, while overdoses are equally common in those over 25, but lower among those under $25 .{ }^{214}$ Whether Afro-Caribbeans actually do have lower rates of minor psychiatric problems (which seems unlikely), the psychiatric perception of their illnesses is that they are more somatic: West Indians are seldom offered psychotherapy and are more likely to be given electroconvulsive therapy and higher doses of medication. ${ }^{15}$

Another troubling aspect of service delivery to AfroCaribbeans is the high admission rate under the Mental
Health Act and the overrepresentation of black patients in secure units and special hospitals. ${ }^{16}$ Doctors explain these figures by saying that illness among black patients is more antisocial or that stigmatisation of mental illness by West Indians leads to a poor relationship between them and psychiatry. ${ }^{17}$ There is no evidence for either of these explanations. We know little about stigmatisation of mental illness in any minority group (or, indeed, among the white population). By contrast, a now justifiably alarmed black community argues that racism in psychiatry is highlighted by the frequency of the controversial diagnosis of "cannabis psychosis," which in some psychiatric hospitals is given to over a quarter of Afro-Caribbean men ${ }^{18}$ (R Littlewood, unpublished observations). Black Britons have responded by establishing psychiatric aftercare facilities for black patients.

Children of immigrants usually have a similar rate of psychiatric illness to the population among which their parents have settled, but disturbingly this is not so in Britain for the children of West Indian immigrants. Two recent studies suggest that their first admission rates for schizophrenia are even higher than those of their parents. McGovern and Cope found that the figure for British born Afro-Caribbean men was seven times the white rate, and for women it was 13 times higher..$^{18}$ In a prospective study Harrison and others found a mean annual incidence rate 16 times higher for British born Afro-Caribbeans aged 16-29 than for British born whites. ${ }^{19}$ Both papers reject explanations in terms of genetics or "West Indian culture." Could misdiagnosis be responsible? Harrison and his colleagues, using the present state examination, found a similar excess at all degrees of a "certainty of schizophrenia" coding. We think that an important aetiological factor is the precipitation of schizophrenia in those vulnerable by the experience of racism refracted through subtle cognitive changes, including selfhood, autonomy, and locus of control.

Because British born blacks are mostly young we have only recently been able to look at adult mental illness. The 
patients in these two studies are nearly all aged 16 to 29 . One explanation of the high schizophrenia rates might be a cohort phenomenon (similar to that suggested for the migrant generation ( $\mathrm{G} R$ Glover, unpublished observations)), in which the children of a particular age group of immigrants are especially vulnerable. Alternatively, susceptible AfroCaribbeans might develop schizophrenia when younger. The truth will become clear in another 10 years. Longitudinal studies may show a prognosis that is more benign for whites than blacks or relatively few new cases of schizophrenia developing in an older population. It would thus be premature to speculate on lifetime morbidity risks, but the high schizophrenia rates among British born Afro-Caribbeanswhether attributable to misdiagnosis, racism, or other factors -must remain a matter of great concern.

RoLAND LitTLEWOOD

Departments of Psychiatry and Anthropology, University College London,

London WC1E 6BT

Department of Psychological Medicine, Guy's Hospital,

London SE1 9RJ
1 Rwegellera GGC. Psychiatric morbidity among West Africans and West Indians living in London. Psychol Med 1977;7:317-29.

2 Cochrane R. Mental illness in immigrants to England and Wales. Soc Psychiatry 1977;12:25-35.

3 Dean G, Walsch D, Downing H, Shelley E. First admissions of native-born and immigrants to psychiatric hospitals in South-East England. Br f Psychiatry 1981;239:506-12.

Carpenter L, Brockington IF. A study of mental illness in Asians, West Indians and Africans living in Manchester. Brf Psychiatry 1980;137:201-5.

5 Littlewood R, Lipsedge M. Some social and phenomenological characteristics of psychotic immigrants. Psychol Med 1981;11:289-302.

6 Giggs J. Ethnic status and mental illness in urban areas. In: Rathwell J, Phillips D, eds. Health, Race and Ethnicity. London: Croom Helm, 1986:137-74.

8 Bagley C. The social aetiology of schizophrenia in immigrant groups. Int $f$ Soc Psychiatry 1971;3:449-59.

9 Bebbington PE, Hurry J, Tennant C. Psychiatric disorders in selected immigrant groups in Camberwell. Soc Psychiatry 1981;16:43-51.

10 Littlewood R, Lipsedge M. Acute psychotic reactions in Caribbean-born patients. Psychol Med 1981;11:303-18.

11 Cochrane R, Bal S. Migration and schizophrenia: an examination of five hypotheses. Soc Psychiatry (in press).

12 Glover GR. 993 W. Birthplace not stated or born at sea. Psychol Med (in press).

13 Burke A. Racism and psychological disturbance among West Indians in Britain. Int 7 Soc Psychiatry 1984;30:50-68.

14 Merrill J, Owens J. Ethnic differences in self-poisoning: a comparison of West Indian and white groups. Br f Psychiatry 1987;150:765-8.

15 Littlewood R, Cross S. Ethnic minorities and psychiatric services. Sociology of Health and Illness 1980;2:194-201.

16 McGovern D, Cope RV. The compulsory detention of males of different ethnic groups. $\mathrm{Br} f$ Psychiatry 1987;150:505-12.

17 Littlewood R. Ethnic minorities and the Mental Health Act: patterns of explanation. Bulletin of the

MAURICE LIPSEDGE $\begin{gathered}\text { Royal College of Psychiatrists 1986:10:306-8. } \\ 18 \text { McGovern D, Cope RV. First admission rates of first and second generation Afro-Caribbeans. Soc }\end{gathered}$ Psychiatry (in press).

19 Harrison G, Owens D, Holton A, Neilson D, Boot D. A prospective study of severe mental disorder in Afro-Caribbean patients. Psychological Medicine (in press).

\section{Ready, steady, go: making doctors compete}

The long running battle by the government to stop restrictive practices in the professions moved up a gear last month when the Department of Trade and Industry published a consultation paper that recommends replacing existing legislation by much stronger deterrents to anticompetitive practices. ${ }^{1}$

It was soon after services were brought within the scope of the Monopolies Commission in 1965 that a Labour government asked it to report on the "general effect on the public interest" of seven specified practices, including restrictions on entry, fee charging, and advertising. ${ }^{2}$ The evidence given by the BMA and General Medical Council seems to have convinced the commission that restrictive practices in medicine were not contrary to public interest, ${ }^{3}$ although many other professions did attract censure. When the restrictive trade practices legislation was extended to include services in 1976, medical services were specifically excluded from the more important of its provisions. In 1985 the Minister for Corporate and Consumer Affairs did, however, include medicine when he asked the Office of Fair Trading to examine what changes had been made to their rules by the various professional bodies in response to the report of the Monopolies Commission. ${ }^{4}$ In fact by 1986 only a few professional bodies still retained a general restriction. They included barristers, whose restrictions had been already cleared by the commission, consulting engineers, doctors, and certain professions allied to medicine. These professions allied to medicine were the subject of a report issued by the office in 1986, which said that concern over patients being misled was not sufficient justification for banning advertisements and that enough control could be achieved by a general requirement for a high standard of ethical and professional conduct together with detailed guidance from the British Code of Advertising Practice and the code of the Independent Broadcasting Authority. ${ }^{5}$ Their professional bodies are thus either considering amending their rules or have already done so.
Failure to adopt the Office of Fair Trading's recommendations attracts consequences, such as a further reference to the Monopolies Commission, that few professions have been willing to risk. One dissentient, the General Council of Osteopaths, has already been referred and is being strongly supported by the BMA, a relationship which might otherwise be thought to be unusual. Medicine has been left until last on the office's list, ostensibly to allow discussions on the green paper on primary care but in practice because it is the hardest nut to crack. The initial skirmishes between the Office of Fair Trading and the BMA and the GMC have now taken place, and it is already clear that a long and hard battle is about to be fought.

The new consultation paper recommends that the registration requirements, from which medical services are currently exempted, should disappear and be replaced by a provision making all anticompetitive agreements and practices illegal unless the parties concerned can convince the Competition Authority to be set up under the new legislation that they should be exempted. The onus will therefore be on the organisations to make the case for exemption, and any organisation caught operating an anticompetitive practice that has not been exempted will be heavily penalised. Time will be provided for anticompetitive practices currently exempted to get exempted under the new law. "Provisional validity" will be granted until a cut off date, after which they will no longer be protected, but each and every anticompetitive practice will have to be justified. The Competition Authority will be based on the existing Office of Fair Trading but will have new and fierce teeth.

The alarm bells are already ringing among doctors, particularly as the government's document says little about the principles that the new authority will apply in granting exemptions. The procedure will be to decide whether an agreement is anticompetitive and then to decide whether it can be exempted. The paper anticipates that "many 